\title{
EFEKTIFITAS TEHNIK RELAKSASI NAPAS DALAM DENGAN MENIUP BALING- BALING TERHADAP PENURUNAN SKALA NYERI PUNGSI VENA PADA ANAK USIA PRASEKOLAH
}

\author{
Toha Machsun ${ }^{1}$, Dera Alfiyanti ${ }^{2}$, Mariyam $^{3}$ \\ Universitas Muhammadiyah Semarang \\ maksuntoha@yahoo.com
}

\begin{abstract}
Abstrak
Nyeri merupakan penyebab stressor pada anak saat hospitalisasi, salah satu penyebabnya yaitu prosedur invasif pungsi vena. Manajemen nyeri merupakan kebutuhan dasar yang harus didapatkan anak saat menjalani hospitalisasi, salah satunya yaitu terapi non farmakologi dengan cara teknik relaksasi nafas dalam dengan meniup baling-baling. Penelitian ini bertujuan untuk mengetahui pengaruh teknik relaksasi nafas dalam dengan meniup baling-baling terhadap skala nyeri pungsi vena pada anak usia prasekolah di Rumah Sakit Roemani Muhammadiyah Semarang. Metode penelitian ini adalah quasy eksperimen dengan pendekatan non equivalent control grup after only desaign. Sampel penelitian ini adalah anak usia prasekolah yang dilakukan tindakan pungsi vena pengambilan darah dengan jumlah sampel 19 kelompok intervensi dan 19 kelompok kontrol. Skala nyeri pungsi vena dikaji menggunakan instrument FLACC. Analisa data menggunakan uji mann whitney. Hasil penelitian menunjukkan rerata skala nyeri pada kelompok intervensi adalah 6 dan pada kelompok kontrol adalah 8. Ada pengaruh teknik relaksasi nafas dalam dengan meniup baling-baling terhadap skala nyeri pungsi vena pada anak usia prasekolah di Rumah Sakit Roemani Muhammadiyah Semarang dengan nilai p value $0,000(\alpha<0,05)$. Diharapkan perawat dapat memberikan teknik relaksasi nafas dalam dengan meniup baling-baling pada anak saat dilakukan pungsi vena untuk mengurangi rasa nyeri.
\end{abstract}

Kata kunci: relaksasi, skala nyeri, pungsi vena

\begin{abstract}
Pain was a cause of stressor in children during hospitalization, one of the causes was the invasive procedure of venous puncture. Pain management was a basic need that must be obtained by children while undergoing hospitalization, one of them was non-pharmacological therapy by means of deep breath relaxation technique by blowing the propeller. This research aimed at determined the influence of deep breath relaxation techniques by blowing the propeller toward the pain scale of venous puncture in preschoolers at Roemani Muhammadiyah Semarang Hospital. This research method was quasy experiment with non equivalent control group after only desaign approach. The sample of this research was preschool age children who performed the venous blood-taking puncture action with a sample of 19 intervention groups and 19 control groups. The vein puncture pain scale was studied using FLACC instruments. The results showed that the pain scale in the intervention group was 6 and in the control group it was 8. There was an influence of deep breath relaxation techniques by blowing the propeller to the pain scale of venous puncture in preschoolers at Roemani Muhammadiyah Semarang Hospital, ( $p$ value 0,000 $<\alpha$ $=0,05)$. It's expected that nurse can provide deep breathing relaxation techniques by blowing the blades child during venous puncture to reduce pain
\end{abstract}

Keyword: relaxation, pain scale, venous puncture 


\section{Pendahuluan}

Pada tahun 2014 jumlah angka kesakitan anak berdasarkan survei kesehatan nasional (susenas) yaitu 15,26\%. Jumlah angka kesakitan anak di daerah perdesaan yaitu sebesar 15,75\%, sedangkan jumlah angka kesakitan anak di daerah perkotaan yaitu sebesar $14,74 \%$. Tidak ada perbedaan yang signifikan antara angka kesakitan anak laki-laki dan perempuan yaitu $15,39 \%$ dan 15,13\% (Survei kesehatan nasional, 2014). Jumlah pasien usia prasekolah yang dirawat di Rumah Sakit Roemani Muhammadiyah Semarang tahun 2016 yaitu 958 anak.

Perawatan di rumah sakit (hospitalisasi) sering kali menjadi krisis pertama yang harus dihadapi anak, terutama saat dilakukan perawatan di rumah sakit. Anak sangat rentan terhadap stress akibat perubahan dari keadaan sehat dan rutinitas lingkungan. Anak memiliki reaksi koping yang terbatas untuk menyelesaikan stressor (kejadian-kejadian yang menimbulkan stress). Stressor utama pada anak saat hospitalisasi antara lain perpisahan, kehilangan kendali, cedera tubuh dan nyeri (Wong, 2009).

Nyeri merupakan pengalaman yang sangat individual dan subjektif yang dapat mempengaruhi orang dewasa dan anak di semua usia. Nyeri dapat berasal dari sejumlah penyebab, antara lain proses penyakit, cedera, prosedur dan intervensi. Anak memiliki kekurangan kapasitas verbal untuk menjelaskan nyeri yang dirasakan, oleh karena itu nyeri merupakan sumber utama distress pada anak. Jika tidak dikelola dengan baik, nyeri pada anak akan menyebabkan trauma fisik dan emosi yang serius. Pengalaman nyeri yang tidak ditangani sedini mungkin dapat menyebabkan konsekuensi fisiologis dan psikologis pada anak dalam jangka waktu yang panjang (Kyle, 2015).

Prosedur yang sering menimbulkan nyeri pada saat hospitalisasi yaitu prosedur pungsi vena. Prosedur pungsi vena merupakan tindakan invasive yang sangat menakutkan bagi anak saat dirawat di rumah sakit. Prosedur pungsi vena merupakan prosedur tindakan yang menyakiti tubuh dan menimbulkan rasa nyeri yang berat sehingga menyebabkan menjadi trauma saat dilakukan tindakan (Wong, et al, 2009). Berdasaran penelitian (Ulfah, 2014) pada kelompok yang tidak diberikan intervensi skala nyeri pada anak saat dilakukan pungsi vena yaitu skala 7 (nyeri sekali) yang diukur dengan skala nyeri FLACC (face, leg, activity, cry, and consolability).

Manajemen nyeri merupakan kebutuhan dasar yang harus didapatkan oleh anak saat menjalani hospitalisasi. Manajemen nyeri dapat dilakukan dengan dua cara yaitu farmakologi dan non farmakologi. Terapi non farmakologi yang sering digunakan yaitu hipnotis, distraksi dan teknik relaksasi nafas dalam (Kyle, 2015). Manajemen nyeri non farmakologi yang sering digunakan yaitu teknik relaksasi nafas dalam.Teknik relaksasi nafas dalam merupakan teknik untuk mengurangi ketegangan nyeri dengan merelaksasikan otot (Wong, 2009).

Berdasarkan penelitian (Widieati, 2015) teknik relaksasi nafas dalam sangat efektif untuk menurunkan intensitas nyeri. Penurunan intensitas nyeri pada responden dikarenanakn peningkatan fokus terhadap nyeri yang beralih pada relaksasi nafas, sehingga suplai oksigen dalam jaringan akan meningkat dan otak bisa berelaksasi. Otak yang berelaksasi akan merangsang tubuh untuk menghasilkan hormon endorpin yang menghambat transmisi inpuls nyeri ke otak yang dapat menurunkan sensasi nyeri sehingga menyebabkan intensitas nyeri yang dialami responden berkurang.

Pada anak manajemen non farmakologi yang sering digunakan yaitu teknik relaksasi nafas dalam. Teknik relaksasi nafas dalam sangat sulit diberikan 
kepada anak, karena anak sangat sulit untuk mengikuti instruksi yang diberikan oleh perawat. Salah satu cara agar anak dapat melakukan relaksasi nafas dalam yaitu dengan melakukan kegiatan bermain. Kegiatan bermain dapat mengalihkan ketegangan dan stress yang dialami anak saat dilakukan pungsi vena, karena mengalihkan rasa nyerinya dengan kegiatan bermain. Permainan yang dapat menimbulkan efek nafas dalam pada anak tanpa diberikan instruksi oleh perawat yaitu meniup gelembung dengan sedotan, meniup balon dan meniup baling-baling kertas (Erfandi, 2009; Wong, et al, 2009).

Penelitian (Syamsudin,

pemberian teknik relaksasi nafas dalam dengan meniup baling-baling kertas sangat efektif digunakan untuk menurunkan intensitas nyeri. Intensitas nyeri pada anak post operasi selama selama dilakukan perawatan luka yang diberikan teknik relaksasi nafas dalam meniup baling-baling kertas skala nyerinya lebih rendah dibandingkan dengan anak yang tidak diberikan teknik relaksasi.

Studi kasus yang dilakukan pada 5 pasien saat dilakukan tindakan pungsi vena, pasien mengalami nyeri yang sangat hebat sehingga orang tua tidak bias menenangkan anak saat dilakukan tindakan pungsi vena, sehingga dapat menyebabkan trauma pada anak. Berdasarkan latar belakang diatas, maka penulis tertarik untuk melakukan penelitian tentang "Pengaruh Teknik Relaksasi Napas Dalam Dengan Meniup Baling-baling Terhadap Skala Nyeri Pungsi Vena Pada Anak Usia Prasekolah”.

\section{Metode}

Jenis penelitian yang digunakan adalah Quasy-eksperimen dengan menggunakan rancangan non equivalent control grup, after only desaign karena penelitian ini tidak melakukan pengukuran sebelum dilakukan intervensi (Notoatmodjo, 2014). Dalam penelitian ini populasi adalah anak usia prasekolah yang di rawat di Ruang Ayyub 3 Rumah Sakit Roemani Muhammadiyah Semarang sebanyak 52 anak. Cara pengambilan sampel ini adalah dengan teknik purposive sampling sehingga jumlah sampel menjadi 38 anak. Penelitian dilakukan di Ruang Ayyub 3 Rumah Sakit Roemani Muhammadiyah Semarang.

Pada kelompok intervensi diberikan penjelasan 1 hari sebelum dilakukan pengambilan darah tentang teknik relaksasi nafas dalam dengan meniup baling-baling. Pada saat dilakukan pengambilan darah responden kembali di jelaskan kembali tentang teknik relaksasi nafas dalam meniup baling-baling. Responden meniup balingbaling sebelum dilakukan pengambilan darah sampai selesai dilakukan pengambilan darah. Pada saat pengambilan darah dan responden meniup baling-baling, dan dilakukan penilaian skala nyeri.

Pada kelompok kontrol diberikan penjelasan tentang nafas dalam 1 hari sebelum dilakukan pengambilan darah. Sebelum pengambilan darah pasien di beritahu kembali cara relaksasi nafas dalam. Pada saat pengambilan darah responden melakukan nafas dan dilakukan penilaian skala nyeri.

Penilaian skala nyeri dilakukan dengan skala nyeri FLACC.Data dianalisis secara univariat dan bivariat dengan uji Mann Whitney.

\section{Hasil}

Karakteristik umur responden pada kelompok intervensi dan kelompok kontrol nilai tengah 4,5 tahun, jenis kelamin paling banyak pada kelompok intervensi laki-laki 10 responden dan kelompok kontrol laki-laki 10 responden, pengalaman prosedur invasif pada kelompok intervensi paling banyak pernah dilakukan 10 responden dan kelompok kontrol paling banyak tidak pernah dilakukan 12 responden. Skala nyeri 
pada kelompok intervensi terendah skala 5 dan tertinggi skala 7 dengan nilai tengan 6 , frekuensi nyeri sedang 17 responden dan nyeri berat 2 responden. Skala nyeri pada kelompok kontrol terendah skala 6 dan tertinggi skala 8 dengan nilai tengah 8 , frekuensi nyeri sedang 6 responden dan nyeri berat 13 responden.

Tabel 1. Distribusi skala nyeri pada saat dilakukan pungsi vena pada kelompok intervensi dengan teknik relaksasi nafas dalam dengan meniup baling-baling, $(\mathrm{n}=19)$

\begin{tabular}{cccccc} 
& $\mathrm{n}$ & Min & Maks & Median & $\begin{array}{c}\text { Standar } \\
\text { Deviasi }\end{array}$ \\
\hline $\begin{array}{c}\text { Skala } \\
\text { Nyeri }\end{array}$ & 19 & 5 & 7 & 6,00 & 0,567 \\
\hline
\end{tabular}

Tabel 2. Distribusi kategori skala nyeri pada saat dilakukan pungsi vena pada kelompok intervensi dengan teknik relaksasi nafas dalam dengan meniup baling-baling, $(\mathrm{n}=19)$

\begin{tabular}{cccc}
\hline Kategori Nyeri & Frekuensi & Persentase \% & Total \\
\hline Nyeri sedang & 17 & 89,5 & 19 \\
Nyeri berat & 2 & 10,5 & $100 \%$ \\
\hline
\end{tabular}

Tabel 3. Distribusi skala nyeri pada saat dilakukan pungsi vena pada kelompok kontrol dengan teknik relaksasi nafas dalam, $(n=19)$

\begin{tabular}{llllll}
\hline & $\mathrm{n}$ & Min & Max & Median & $\begin{array}{l}\text { Standar } \\
\text { Deviasi }\end{array}$ \\
\hline $\begin{array}{l}\text { Skala } \\
\text { Nyeri }\end{array}$ & 19 & 6 & 8 & 8,00 & 0,918 \\
\hline
\end{tabular}

Tabel 4. Distribusi kategori nyeri pada saat dilakukan pungsi vena pada kelompok kontrol dengan teknik relaksasi nafas dalam, $(n=19)$

\begin{tabular}{cccc}
\hline $\begin{array}{c}\text { Kategori } \\
\text { nyeri }\end{array}$ & Frekuensi & Persentase \% & Total \\
\hline $\begin{array}{c}\text { Nyeri } \\
\text { sedang }\end{array}$ & 6 & 31,6 & 19 \\
Nyeri berat & 13 & 64,8 & $100 \%$ \\
\hline
\end{tabular}

Tabel 5. Pengaruh teknik relaksasi nafas dalam dengan meniup baling-baling terhadap skala nyeri pungsi vena pada anak usia prasekolah di RS Roemani Muhammadiyah Semarang, $(n=38)$

\begin{tabular}{cccc}
\hline Variabel & Kelompok & Mean & $p$ value \\
\hline Skala nyeri & Intervensi & 6 & 0,000 \\
& Kontrol & 8 & \\
\hline
\end{tabular}

\section{Pembahasan}

Skala nyeri anak pada saat dilakukan pungsi vena pada kelompok intervensi dengan teknik relaksasi nafas dalam meniup baling-baling.

Hasil penelitian yang dilakukan pada saat diberikan teknik relaksasi nafas dalam dengan meniup baling-paling pada saat dilakukan pungsi vena skala nyeri anak yaitu skala 6 dengan kriteria nyeri sedang. Jumlah responden dengan skala nyeri sedang yaitu 17 responden dengan persentase $89,5 \%$ dan skala nyeri berat 2 responden 10,5\%. Berdasarkan penelitian Noel, et al (2012) responden yang mempunyai pengalaman prosedur invasif sebelumnya dapat mempengaruhi skala nyeri pada saat dilakukan prosedur invasif selanjutnya. Nyeri berat yang terjadi disebabkan karena anak masih ketakutan dan belum memiliki pengalaman prosedur invasif. Pada anak yang diberikan relaksasi nafas dalam dengan meniup baling-baling skala nyerinya rendah karena saat dilakukan pungsi vena perhatian anak beralih ke permainan meniup balingbaling, sehingga tidak terlalu nyeri.

Pada anak untuk mendapatkan efek relaksasi sangat sulit dilakukan, maka untuk mendapatkannya dilakukan dengan cara terapi bermain yang salah satunya yaitu dengan meniup baling-baling. Penurunan intensitas nyeri tersebut dikarenakan adanya peningkatan fokus terhadap nyeri yang dialami responden yang beralih pada relaksasi sehingga suplai oksigen dalam jaringan akan meningkat dan otak bisa berelaksasi. Otak yang relaks tersebut akan 
merangsang tubuh untuk menghasilkan hormon endorphin untuk menghambat tranmisi inpuls nyeri ke otak dan nyeri akan berkurang (Wong, 2009).

Hasil penelitian ini juga didukung oleh hasil penelitian Syamsudin (2015) bahwa teknik relaksasi nafas dalam dengan meniup baling-baling dapat menurunkan intensitas skala nyeri pada anak post operasi selama perawatan luka. Intensitas skala nyeri pada anak yang diberkan relaksasi nafas dalam meniup baling-baling skala nyerinya lebih rendah dibandingkan dengan anak yang tidak diberikan relaksasi nafas dalam.

\section{Skala nyeri anak pada saat dilakukan pungsi vena pada kelompok kontrol dengan teknik relaksasi nafas dalam}

Hasil penelitian yang dilakukan pada anak saat dilakukan pungsi vena pada kelompok kontrol dengan teknik relaksasi nafas dalam skala nyeri anak yaitu 8 dengan kriteria nyeri berat. Jumlah responden dengan skala nyeri sedang yaitu 10 responden dengan persentase $31,6 \%$ dan nyeri berat 13 responden dengan persentase $64,8 \%$. Nyeri sedang pada responden disebabkan karena anak sebelumnya sudah mempunyai pengalaman prosedur invasif sehingga memiliki manajemen nyeri yang lebih bagus. Berdasarkan penelitian Noel, et al (2012) responden yang mempunyai pengalama prosedur invasif sebelumnya dapat mempengaruhi skala nyeri pada saat dilakukan prosedur invasif selanjutnya. Skala nyeri pada anak yang diberikan relaksasi nafas dalam saja skala nyerinya masih tinggi, dikarenakan anak masih terfokus pada prosedur tindakan invasif.

Teknik relaksasi nafas dalam kurang efektif diberikan pada anak usia 3-5 tahun dikarenakan anak belum mampu mengikuti instruksi perawat untuk melakukan relaksasi nafas dalam. Anak masih terfokus pada nyeri yang dirasakan, sehingga teknik relaksasi nafas dalam tersebut tidak efektif untuk menurunkan skala nyeri pada anak (Erfandi, 2009).

Pengaruh teknik relaksasi nafas dalam dengan meniup baling-baling terhadap skala nyeri pungsi vena pada anak usia prasekolah

Hasil analisa yang dilakukan terhadap pengaruh teknik relaksasi nafas dalam dengan meniup baling-baling terhadap skala nyeri anak dengan uji mann whitney diketahui $p$ value $0,000<\alpha=0,05$. Hasil penelitian ini menunjukkan adanya pengaruh terknik relaksasi nafas dalam dengan meniup baling-baling terhadap skala nyeri pungsi vena pada anak usia prasekolah di RS Roemani Muhammadiyah Semarang.

Relaksasi nafas dalam merupakan terapi nonfarmakologi yang sangat efektif untuk menurunkan skala nyeri. Pada anak untuk mendapatkan efek relaksasi nafas dalam dilakukan dengan cara terknik terapi bermain meniup baling-baling. Anak akan mengalihkan rasa nyerinya tersebut dengan bermain meniup baling-baling,sehingga rasa nyeri pada anak dapat berkurang (Wong, 2009).

Teknik relaksasi nafas dalam mampu merangsang tubuh untuk melepaskan hormon opioid endorphine dan enfelaktin. Hormon endorfine merupakan hormone sejenis morfin yang berfungsi menghambat tranmisi implus nyeri ke otak. Saat neuron nyeri mengirimkan sinyal ke sinaps, terjadi sinapsis antara neuron perifer dan neuron yang menuju otak tempat seharusnya substansi P akan menghasilkan impuls. Pada saat tersebut, endorphin akan memblokir lepasnya substansi $\mathrm{P}$ dari neuron sensorik, sehingga sensasi nyeri akan berkurang (Smeltzer \& Bare, 2002).

Penurunan skala nyeri yang dialami responden dikarenakan oleh peningkatan fokus terhadap nyeri yang dialami responden beralih pada relaksasi nafas dalam dengan 
meniup baling-baling, sehingga suplai oksigen dalam jaringan akan meningkat dan otak akan berelaksasi. Otak yang berelaksasi akan merangsang tubuh utuk menghasilkan hormon endorphin untuk menghambat tranmisi impuls nyeri ke otak dan dapat menurunkan sensasi terhadap nyeri yang akan menyebabkan internsitas nyeri berkurang (Perry \& Potter, 2010).

Penelitian Syamsudin menjelaskan pemberian terapi relaksasi nafas dalam dengan meniup baling-baling kertas efektif dapat menurunkan intensitas kala nyeri pada anak post operasi selama perawatan luka. Intensitas nyeri pada kelompok intervensi lebih rendah daripada kelompok kontrol.

Penelitian Wahyuni, Setyawati, Inayah (2015) menjelaskan bahwa pemberian terapi slow deep breathing dengan meniup baling-baling sangat berpengaruh terhadap penurunan intesitas nyeri pada anak saat dilakukan penyuntikan anestesi umum dengan hasil intensitas nyeri pada kelompok intervensi lebih rendah daripada kelompok kontrol.

\section{Kesimpulan}

Skala nyeri pada anak yang diberikan relaksasi nafas dalam dengan meniup balingbaling yaitu skala nyeri sedang sebesar $89,5 \%$. Skala nyeri pada anak yang diberikan relaksasi nafas dalam yaitu skala nyeri berat sebesar $64,8 \%$. Ada perbedaan skala nyeri antara kelompok intervensi dan kelompok kontrol ( $\mathrm{p}$ value $0,000<\alpha=$ 0,05), sehingga dapat disimpulkan ada pengaruh teknik relaksasi nafas dalam dengan meniup baling-baling terhadap skala nyeri pungsi vena pada anak usia prasekolah di RS Roemani Muhammadiyah Semarang.

Bagi institusi pelayanan kesehatan diharapkan terapi relaksasi nafas dalam dengan meniup baling-baling dapat menjadi Standar Operasional Prosedur (SOP) dalam manajemen nyeri anak yang dilakukan prosedur invasif. Bagi rumah sakit diharapkan menjadi Sandar Operasional Prosedur (SOP) untuk manajemen nyeri. Bagi peneliti diharapkan dapat.

\section{Daftar Pustaka}

Erfandi. (2009). Bermain bagi pasien anak di rumah sakit. Retrieved March 3, 2009, from https://forbetterhealth.wordpress.com/2 009/01/19/bermain-bagi-pasien-anakdi-rumah-sakit/

Noel, M., Chambers, c.T., McGrath, P.J., Klein, R.M., \& Stewart, S. . (2012). The Influence of children's pain memories on subsequent pain experiance.

Notoatmodjo, S. (2014). Metodologi penelitian kesehatan. Jakarta: RINEKA CIPTA.

Perry, P. \&. (2010). Fundamental Keperawatan (7th ed.). Jakarta: Salemba Medika.

Smeltzer, \& B. (2002). Keperawatan Medikal Bedah (8th ed.). Jakarta: EGC.

Survey kesehatan nasional. (2014). profil anak indonesia 2015. Kementerian Pemberdayaan Perempuan dan Perlindungan Anak (KPP\&PA).

Syamsudin, A. (2015). Bermain meniup baling-baling kertas untuk menurunkan intensitas nyeri pada anak saat perawatan luka operasi. Jurnal Kesehatan Ilmiah Nawasukes, 8.

Terri kyle., S. C. (2015). Buku Ajar Keperawatan Pediatri (Edisi 2 Vo). Jakarta: EGC. 
Ulfah, S. (2014). pengaruh pemberian larutan gula terhadap skala nyeri anak usia 3-4 tahun yang dilakukan pungsi vena di RSUD Tugurejo Semarang. Jural Ilmu Keperawatan Dan Kebidanan.

Wahyuni, Setyawati, I. (2015). Terapi Slow Deep Breathing Dengan Bermain Meniup Baling-baling Terhadap Intensitas Nyeri Pada Anak Yang Dilakukan Penyuntikan Anestesi Sirkumsisi. Skolastik Keperawatan, 1.

Widieati, W. (2015). Pengaruh teknik relaksasi nafas dalam terhadap penurunan intensitas nyeri pada ibu postseksio sesarea di rumah sakit unipdu medika Jombang. Jurnal Edu Health, 2.

Wong, D. L. (2009). Buku Ajar Keperawatan Pediatri (Edisi 6 Vo). Jakarta: EGC.

Wong, Donna L., et al. (2009). Buku Ajar Keperawatan Pediatric (Volume 2). Jakarta: Buku Kedokteran EGC. 